\title{
HYPNOSIS AND SEXUAL AROUSAL: A META-ANALYSIS
}

\author{
Ratna Dewi Kumalasari'), Didik Gunawan Tamtomo²), Hanung Prasetya3) \\ 1)Masters Program in Public Health, Universitas Sebelas Maret \\ 2)Faculty of Medicine, Universitas Sebelas Maret \\ 3)School of Health Polytechnics, Ministry of Health, Surakarta
}

\begin{abstract}
Background: Marriage problems that often arise often begin with sexual problems. Sexuality is not always focused on coital activity which includes cycles of desire, excitement, orgasm, and resolution but it is also related to non coital activity. Sexual satisfaction refers to a person's pleasant feelings of the type of sexual relationship that forms an important part of the impression of one partner with another which in turn maintains their marriage. 75 percent of all women and 50 percent of all men have experienced sexual difficulties. Sexual dysfunction occurs in almost half of marriages and in about 75 percent of couples who need therapy or assistance in marital problems. This study aimed to analyze the effect of hypnosis in patients with sexual dysfunction.
\end{abstract}

Subjects and Method: This was a meta-analysis and systematic review. The articles were obtained from Pubmed, Science Direct, Springer Link, and Google Scholar electronic databases. Keywords to search articles were "non-medical therapy", "nonmedical treatment", "randomized control trial", "sexual disorder", "sexual function", and "sexual satisfaction". The articles studied were full text articles with observational study design. The articles were collected using PRISMA diagrams and analyzed using the Review Manager 5.3.

Results: Hypnosis increased sexual arousal by 2.16 times compared to not providing the therapy $(\mathrm{OR}=2.16 ; 95 \% \mathrm{CI}=1.76$ to $2.56 ; \mathrm{p}<0.001)$.

Conclusion: Hypnosis increases sexual arousal.

Keywords: Hypnosis, sexual arousal, meta analysis

Correspondence:

Ratna Dewi Kumalasari. Masters Program in Public Health, Universitas Sebelas Maret. Email: logicakinanthi@gmail.com. Mobile: (+62) 81330542623.

The $7^{\text {th }}$ International Conference on Public Health Solo, Indonesia, November 18-19, 2020 | 409 https://doi.org/10.26911/the7thicph.05.41 